Prepared in cooperation with the Inland Oil Spill Preparedness Project

\title{
Vulnerability Assessment in and near Theodore Roosevelt National Park, North Dakota
}

By Kristen J. Valseth

Pamphlet to accompany

Scientific Investigations Map 3479 


\section{U.S. Geological Survey, Reston, Virginia: 2021}

For more information on the USGS - the Federal source for science about the Earth, its natural and living resources, natural hazards, and the environment—visit https://www.usgs.gov or call 1-888-ASK-USGS.

For an overview of USGS information products, including maps, imagery, and publications, visit https://store.usgs.gov/.

Any use of trade, firm, or product names is for descriptive purposes only and does not imply endorsement by the U.S. Government.

Although this information product, for the most part, is in the public domain, it also may contain copyrighted materials as noted in the text. Permission to reproduce copyrighted items must be secured from the copyright owner.

Suggested citation:

Valseth, K.J., 2021, Vulnerability assessment in and near Theodore Roosevelt National Park, North Dakota: U.S. Geological Survey Scientific Investigations Map 3479, pamphlet 9 p., 1 sheet, https://doi.org/10.3133/sim3479.

Associated data for this publication:

U.S. Geological Survey, 2019, USGS water data for the Nation: U.S. Geological Survey National Water Information System database, https://doi.org/10.5066/F7P55KJN.

ISSN 2329-132X (online) 


\section{Acknowledgments}

This work was supported by funding from the Department of the Interior's Inland Oil Spill Preparedness Project. 



\section{Contents}

Acknowledgments ……...................................................................................................................

Abstract

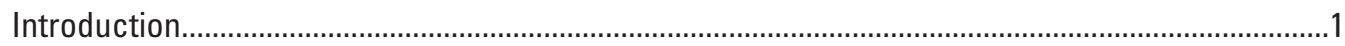

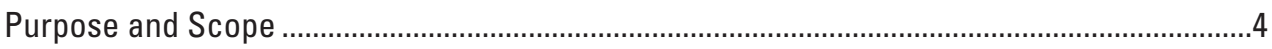

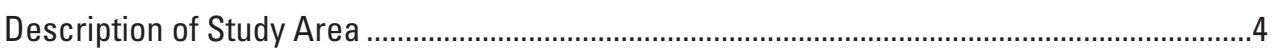

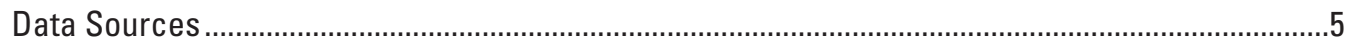

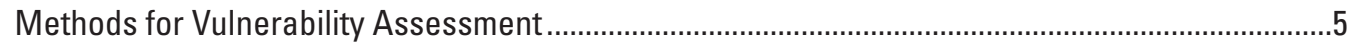

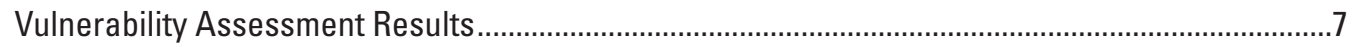

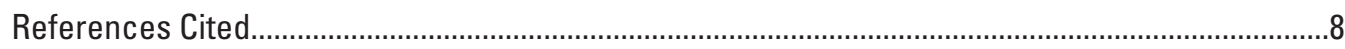

\section{Figures}

1. Map showing study area and select water resources and critical components in and near Theodore Roosevelt National Park, North Dakota..........................................2

2. Map showing oil and gas development and transportation infrastructure surrounding Theodore Roosevelt National Park, North Dakota ........................................

3. Maps showing vulnerability scores for each unit of the study area .........................sheet 1

4. Maps showing vulnerability scores and stressor flow paths for each unit of

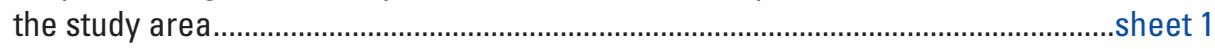

\section{Tables}

1. Select site information for springs identified by the National Park Service for vulnerability assessment in Theodore Roosevelt National Park, North Dakota

2. Vulnerability index values for critical components assessed in Theodore Roosevelt National Park, North Dakota....

\section{Conversion Factors}

U.S. customary units to International System of Units

\begin{tabular}{|c|c|c|}
\hline Multiply & By & To obtain \\
\hline \multicolumn{3}{|c|}{ Length } \\
\hline mile (mi) & 1.609 & kilometer $(\mathrm{km})$ \\
\hline \multicolumn{3}{|c|}{ Area } \\
\hline square mile $\left(\mathrm{mi}^{2}\right)$ & 2.590 & square kilometer $\left(\mathrm{km}^{2}\right)$ \\
\hline \multicolumn{3}{|c|}{ Hydraulic conductivity } \\
\hline foot per day & 0.3048 & meter per second $(\mathrm{m} / \mathrm{d})$ \\
\hline
\end{tabular}

International System of Units to U.S. customary units

\begin{tabular}{lccc}
\hline & Multiply & By & To obtain \\
\hline & Length & \\
\hline meter $(\mathrm{m})$ & 3.281 & foot $(\mathrm{ft})$ & \\
\hline
\end{tabular}




\section{Datum}

Vertical coordinate information is referenced to the North American Vertical Datum of 1988 (NAVD 88).

Horizontal coordinate information is referenced to North American Datum of 1983 (NAD 83).

Altitude, as used in this report, refers to distance above the vertical datum.

\section{Abbreviations}

$\begin{array}{ll}\text { lidar } & \text { light detection and ranging } \\ \text { NPS } & \text { National Park Service } \\ \text { OG } & \text { oil and gas }\end{array}$




\title{
Vulnerability Assessment in and near Theodore Roosevelt National Park, North Dakota
}

\author{
By Kristen J. Valseth
}

\section{Abstract}

Theodore Roosevelt National Park is in western North Dakota and was established in 1978 under the National Wilderness Preservation system to preserve and protect the qualities of the North Dakota Badlands, including the wildlife, scenery, and wilderness. The park is made up of three units (North, Elkhorn Ranch, and South) that are connected by the Little Missouri River, which was identified by the National Park Service as a significant resource essential to fulfilling the park's purpose. The development of oil and gas (OG) resources has expanded in the past two decades in the region surrounding Theodore Roosevelt National Park. This expansion of OG development outside park boundaries increases the potential for adverse environmental and economic effects inside the park boundaries, especially for the hydrologic processes within Theodore Roosevelt National Park.

This report assesses the vulnerability of critical components that contribute to supporting plants and wildlife of the Northwestern Great Plains ecological region and Theodore Roosevelt National Park's mission of preservation. Critical components include land cover, slope, soil saturated hydraulic conductivity, distance to Ovis canadensis (Shaw, 1804) (bighorn sheep) critical habitat, distance to springs, distance to rivers and streams, and distance to surficial aquifers. The study area included all the 12-digit hydrologic units within the watershed boundary dataset that intersect Theodore Roosevelt National Park or are within the 12-digit hydrologic units for Little Missouri River tributaries that flow into the park. Critical components that had existing publicly available geographic data were assessed and assigned vulnerability index values. These values were then summed to develop a vulnerability score and mapped. OG development and associated transportation infrastructure, referred to as "stressors" in this report, with publicly available geographic data were mapped, and then flow paths were generated starting from the stressor locations to assess their likelihood to contaminate vulnerable areas within the study area.

The North Unit had the most area with moderate, high, and very high vulnerability. These areas occurred all across the southern and eastern parts of the North Unit where the Little Missouri River, surficial aquifer, wetland type land covers, and bighorn sheep critical habitat are present. Several stressor flow paths from pipelines and highways cross these areas and may pose the most risk to the vulnerable areas identified. In the Elkhorn Ranch Unit, areas with moderate, high, and very high vulnerability were in the southeastern part of the unit, where the Little Missouri River, surficial aquifer, wetland type land covers, and bighorn sheep critical habitat are present. The stressor flow paths in the Elkhorn Ranch Unit follow the length of the Little Missouri River and all its tributaries in the study area. The stressor flow paths originated from crude oil wells and pipelines. In the South Unit, one area had moderate, high, and very high vulnerability. This area is where the Little Missouri River and bighorn sheep critical range are present. The stressor flow paths in the South Unit follow the length of the Little Missouri River and nearly all its tributaries in the study area. Several stressor flow paths cross the one identified vulnerable area that originated from crude oil wells.

\section{Introduction}

Theodore Roosevelt National Park is in western North Dakota and was established in 1978 under the National Wilderness Preservation system (National Park Service, 2020) to preserve and protect the "scenery, wildlife, and wilderness qualities of the North Dakota Badlands" (National Park Service, 2014, p. 6). The park is made up of three units (North, Elkhorn Ranch, and South; fig. 1) that are connected by the Little Missouri River, which was identified by the National Park Service (NPS) as a significant resource essential to fulfilling the park's purpose (National Park Service, 2014).

All 110 square miles $\left(\mathrm{mi}^{2}\right)$ of Theodore Roosevelt National Park are in McKenzie County (North Unit) or Billings County (Elkhorn Ranch and South Units), and all three units are surrounded by energy development (figs. 1 and 2), such as crude oil wells and pipelines. The park's grassland prairies, riparian cottonwood forests, streams, and springs are critical components for supporting plants and wildlife of the Northwestern Great Plains ecological region (U.S. Environmental Protection Agency, 2010). These critical components of the park provide habitats for a large number of sensitive species, including more than 400 plants and trees; iconic western mammals such as bison, elk, and Ovis canadensis (Shaw, 1804) (bighorn sheep); and one of the few NPS-managed herds of feral horses (Amberg and others, 2014). 


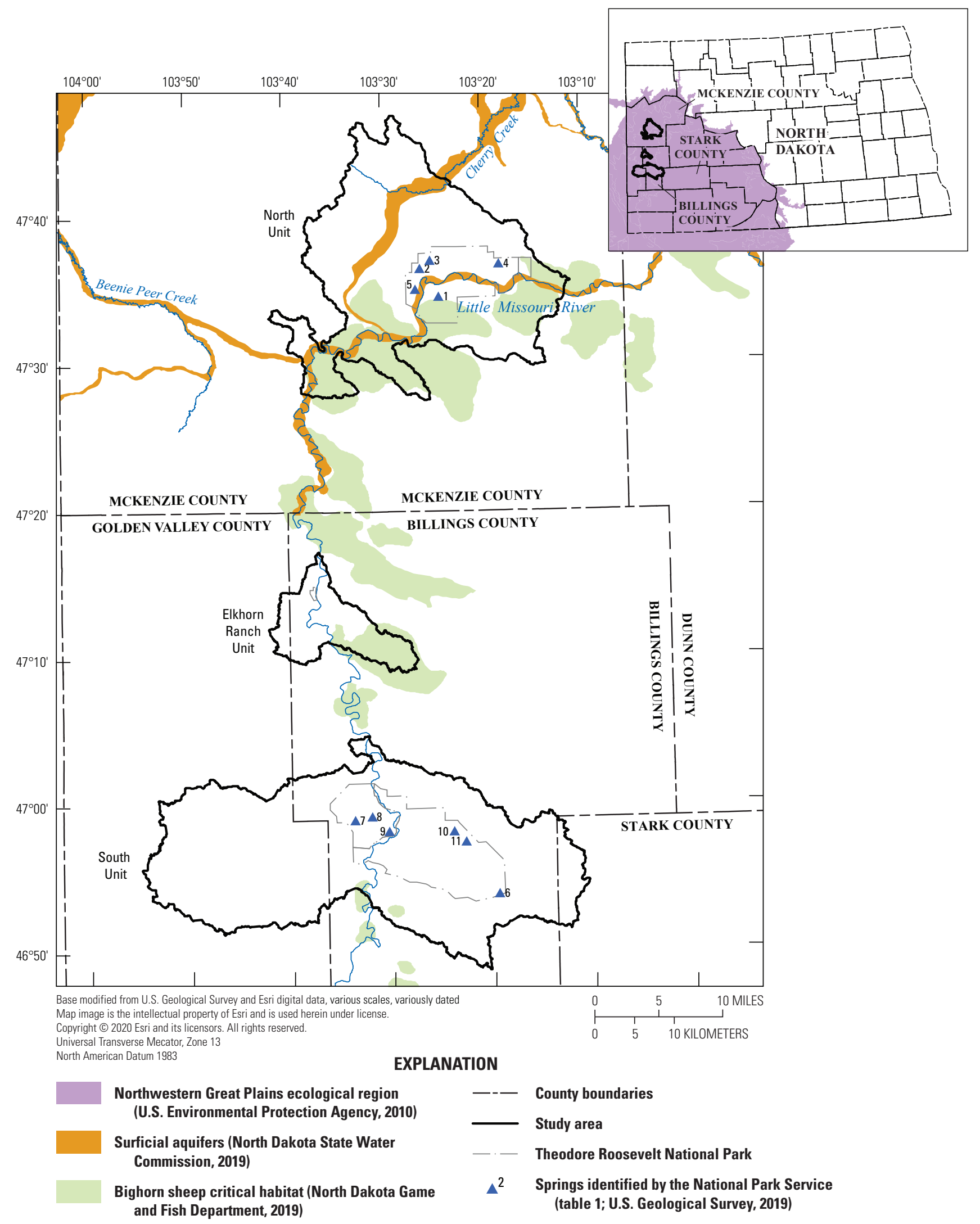

Figure 1. Study area and select water resources and critical components in and near Theodore Roosevelt National Park, North Dakota. 


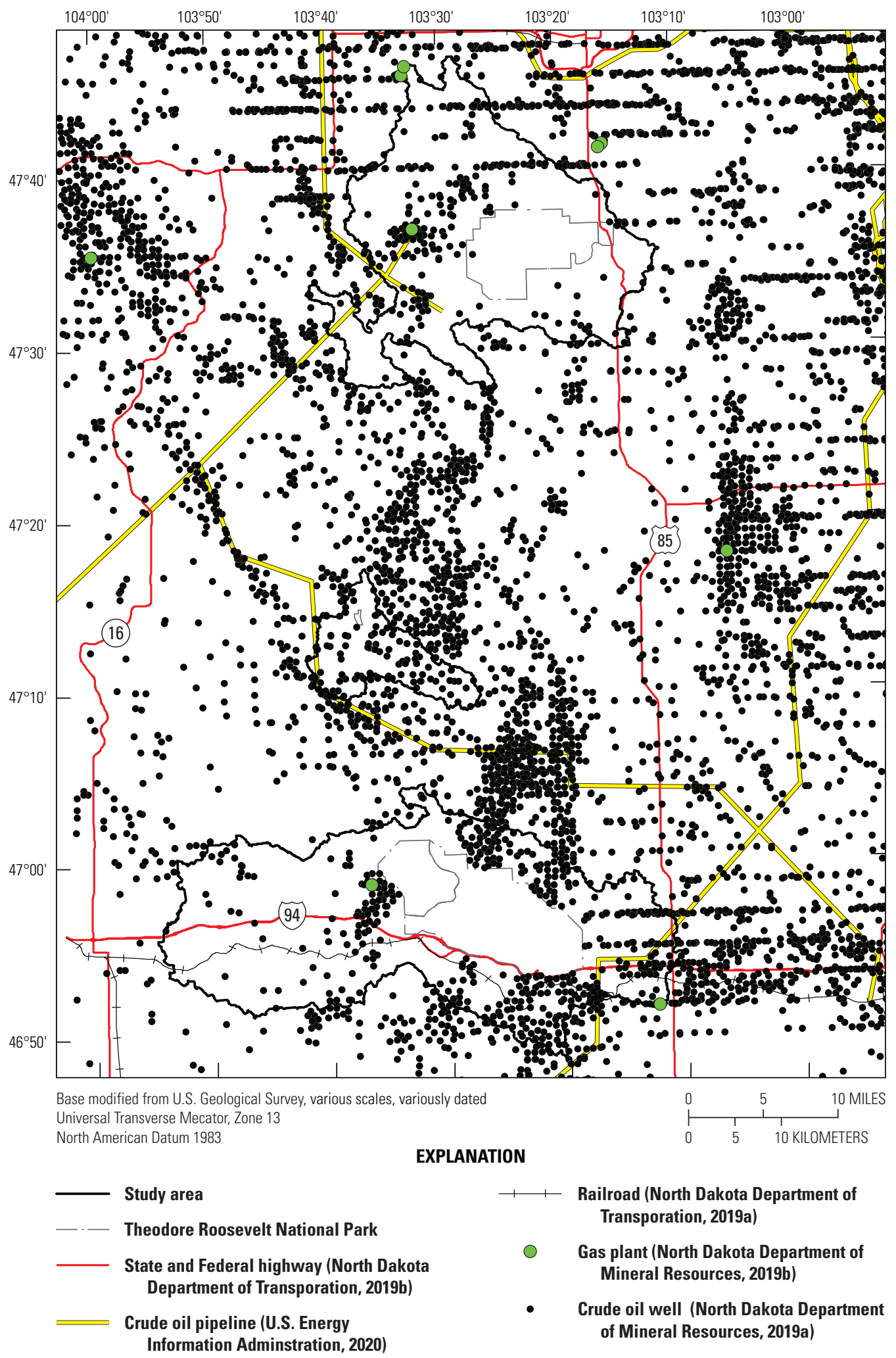

Figure 2. Oil and gas development and transportation infrastructure surrounding Theodore Roosevelt National Park, North Dakota. 
The development of oil and gas (OG) resources requires the transportation of oil and produced water (a byproduct of oil production) from oil fields to refineries, transport terminals, or disposal locations. This transportation is typically done via pipeline, rail, or truck. Although the density of energy development continues to increase outside park boundaries, the potential for adverse environmental and economic effects inside park boundaries from spills and other anthropogenic activities is ever present, especially for the hydrologic processes within Theodore Roosevelt National Park. During the 12-month period from April 2018 to March 2019, a total of 97 contained or uncontained spills in McKenzie and Billings Counties were reported to the North Dakota Department of Health or the Department of Mineral Resources (North Dakota Department of Environmental Quality, 2019).

The NPS identified OG development and the associated risk of spills into tributary streams as threats to the Little Missouri River (National Park Service, 2014). Park managers also have expressed concern that some spill occurrence that directly affects NPS lands will eventually happen.

\section{Purpose and Scope}

This report identifies areas of vulnerability by assessing the vulnerability of critical components that contribute to supporting plants and wildlife of the Northwestern Great Plains ecological region and Theodore Roosevelt National Park's mission of preservation of the qualities of the North Dakota Badlands, including wildlife, scenery, and wilderness. The study area includes 12-digit hydrologic units within the watershed boundary dataset that intersect Theodore Roosevelt National Park or are 12-digit hydrologic units for Little Missouri River tributaries that flow into the park. Critical components that have existing publicly available geographic data were assessed and assigned vulnerability index values that were then summed to a vulnerability score and mapped. OG development and associative transportation infrastructure, referred to as "stressors" in this report, with publicly available geographic data were mapped and then flow paths were generated starting from stressor locations to assess their likelihood to contaminate vulnerable areas within the study area. This report provides a tool to evaluate areas vulnerable to contamination within Theodore Roosevelt National Park to support the timely response to nearby spills.

\section{Description of Study Area}

The study area includes Theodore Roosevelt National Park, which was established in 1947 as Theodore Roosevelt National Memorial Park (South Unit and Elkhorn Ranch Unit) in honor of Theodore Roosevelt (National Park Service, 2014), and the North Unit was added in 1948. In 1978, Congress changed the memorial park to a national park and established the 47-mi² Theodore Roosevelt Wilderness (not shown) within the park's North Unit and South Unit. Theodore Roosevelt National Park is in the North Dakota Badlands (also referred to as the "Little Missouri River Badlands"), where "a rugged landscape of colorful geological formations, varied habitats, and abundant wildlife provide a strikingly dramatic contrast with the rolling mixed-grass prairies in the surrounding region" (National Park Service, 2014, p. 7).

The study area not only includes Theodore Roosevelt National Park but also the 12-digit hydrologic units within the watershed boundary dataset that intersect Theodore Roosevelt National Park or are within the 12-digit hydrologic units boundary for Little Missouri River tributaries that flow into the park. The resulting study area includes the Theodore Roosevelt National Park North, Elkhorn Ranch, and South Units and their selected 12-digit hydrologic units, which consist of a total area of $663 \mathrm{mi}^{2}$ (fig. 1).

Water resources within the study area include the Little Missouri River and its tributaries, springs, and surficial aquifers (fig. 1). The Little Missouri River, which is present in all three park units, carved the Badlands, is an important component in the natural and cultural landscape, and supports riparian cottonwood forests that serve a critical role in the health of the park's ecosystem (National Park Service, 2014). The floodplains of the Little Missouri River, Beenie Peer Creek, and Cherry Creek near the North Unit (fig. 1) are underlain by surficial aquifers that provide hydraulic connections to the overlying river and streams. NPS identified 11 springs (table 1; Eldridge and Medler, 2020) within Theodore Roosevelt National Park that were to be assessed in this study; 5 are in the North Unit, and 6 are in the South Unit (fig. 1). 
Table 1. Select site information for springs identified by the National Park Service for vulnerability assessment in Theodore Roosevelt National Park, North Dakota.

[Latitude and longitude in North American Datum of 1983; USGS, U.S. Geological Survey; NWIS, National Water Information System; ID, identifier]

\begin{tabular}{cllll}
\hline Map number & \multicolumn{1}{c}{ Spring } & USGS NWIS site ID & Latitude & Longitude \\
\hline & & North Unit & & -103.407667 \\
2 & Achenbach & 473432103242801 & 47.575515 & -103.437803 \\
3 & Overlook & 473627103261601 & 47.607618 & -103.420669 \\
4 & Stevens & 473701103251401 & 47.617025 & -103.305396 \\
5 & Hagen & 473644103181901 & 47.612134 & -103.446369 \\
\hline & Mandal & 473509103265101 & 47.58398 & -103.324802 \\
7 & & South Unit & 46.897238 & -103.562341 \\
9 & Southeast Corner & 465350103192901 & 46.98222 & -103.53446 \\
10 & Lone Tree & 465856103334401 & 46.985878 & -103.506246 \\
11 & Sheep Pasture & 465909103320401 & 46.969183 & -103.398856 \\
\hline
\end{tabular}

\section{Data Sources}

Seven critical components were assessed for vulnerability to OG development contamination: land cover, slope, soil saturated hydraulic conductivity, distance to bighorn sheep critical habitat, distance to springs, distance to rivers and streams, and distance to surficial aquifers. All the datasets are publicly available. Land cover from the U.S. Geological Survey (2011) was assessed because the land cover types closely resembled critical habitat types, such as prairie grasslands (herbaceous land cover) and riparian cottonwood forests (woody wetland land cover). Slope derived from a light detection and ranging (lidar) altitude dataset from McKenzie County, North Dakota (2014), and Natural Resources Conservation Service (2017) was assessed because slope could increase the rate of travel, thus reducing response time to spills. The Natural Resources Conservation Service (2017) lidar dataset did not cover a small part of the study area east of the South Unit and in Stark County; this is represented as a blank area within the study area boundary with the label "No lidar data" on applicable figures. Examination of land slopes for the study area in Stark County indicated that any spills that may occur in that area would flow away from Theodore Roosevelt National Park and out of the study area; consequently, no assessment of vulnerabilities was completed in that area. The measure of a saturated soil's capacity to transmit water when subjected to a hydraulic gradient is the saturated hydraulic conductivity, which can be more simply described as the ease in which water moves through the pores of a saturated soil (Natural Resources Conservation Service, 2020). The soil saturated hydraulic conductivity was retrieved from Natural Resources Conservation Service (2019) and was assessed because soils with higher saturated hydraulic conductivity could allow spills to infiltrate and reach groundwater more rapidly, which may then reduce travel time to surface waters and surficial aquifers. Distance to bighorn sheep critical habitat was derived using data from North Dakota Game and Fish Department (2019) and was assessed because bighorn sheep are considered an iconic animal of the west and had been extirpated from the region in the past (National Park Service, 2020). Surface and groundwater resources were explicitly identified by the NPS as being critical components; therefore, the distance to springs (U.S. Geological Survey, 2019; Eldridge and Medler, 2020), rivers, and streams (Esri, 2019) and the distance to surficial aquifers (North Dakota State Water Commission, 2019) were derived and assessed.

The five stressors assessed in this study include crude oil wells, gas plants, railroads, State and Federal highways, and crude oil pipelines (fig. 2). Crude oil wells and gas plants were retrieved from the North Dakota Department of Mineral Resources (2019a, b) Oil and Gas ArcIMS Viewer. Railroads, State highways, and Federal highways were retrieved from the North Dakota Department of Transportation (2019a, b) GIS Hub Data Portal. Crude oil pipelines were retrieved from the U.S. Energy Information Administration (2020).

\section{Methods for Vulnerability Assessment}

The mapped vulnerability scores were developed by summing the vulnerability index values of the seven critical components (table 2) that were aggregated based on geographic areas. Each critical component was designated a vulnerability index value ranging from 0 to 4 , where 0 represents the lowest vulnerability and 4 represents the highest vulnerability, based on criteria listed in table 2. 
Table 2. Vulnerability index values for critical components assessed in Theodore Roosevelt National Park, North Dakota.

$[<$, less than; $\geq$, greater than or equal to; $\leq$, less than or equal to; $\mu \mathrm{m} / \mathrm{s}$, micrometer per second]

\begin{tabular}{|c|c|c|c|c|c|}
\hline Critical components & $\begin{array}{l}\text { Very low } \\
0\end{array}$ & $\begin{array}{c}\text { Low } \\
1\end{array}$ & $\begin{array}{l}\text { Moderate } \\
\quad 2\end{array}$ & $\begin{array}{c}\text { High } \\
3\end{array}$ & $\begin{array}{c}\text { Very high } \\
4\end{array}$ \\
\hline Land cover type & $\begin{array}{l}\text { Barren land, evergreen forest, } \\
\text { mixed forest, shrub/scrub, hay/ } \\
\text { pasture, and cultivated crops } \\
\text { (outside the park boundaries) }\end{array}$ & Herbaceous & $\begin{array}{l}\text { Hay/pasture and cultivated } \\
\text { crops (within the park } \\
\text { boundaries) }\end{array}$ & Deciduous forest & $\begin{array}{l}\text { Open water, woody } \\
\text { wetland, emergent } \\
\text { herbaceous wetlands }\end{array}$ \\
\hline $\begin{array}{l}\text { Saturated hydraulic conductiv- } \\
\text { ity (in } \mu \mathrm{m} / \mathrm{s} \text { ) }\end{array}$ & $<0.1$ & $0.11-1$ & $1.01-10$ & $10.01-100$ & $\geq 100.01$ \\
\hline Slope (percent rise) & $\leq 3$ & $3.1-6$ & $6.1-10$ & $10.1-15$ & $\geq 15.1$ \\
\hline $\begin{array}{l}\text { Distance from surficial aquifer } \\
\text { (in meters) }\end{array}$ & $\geq 201$ & $101-200$ & $61-100$ & $31-60$ & $\leq 30$ \\
\hline $\begin{array}{l}\text { Distance from a river or stream } \\
\text { (in meters) }\end{array}$ & $\geq 201$ & $101-200$ & $61-100$ & $31-60$ & $\leq 30$ \\
\hline $\begin{array}{l}\text { Distance from a spring (in } \\
\text { meters) }\end{array}$ & $\geq 201$ & $101-200$ & $61-100$ & $31-60$ & $\leq 30$ \\
\hline $\begin{array}{l}\text { Distance from critical bighorn } \\
\text { sheep ranges (in meters) }\end{array}$ & $\geq 1,000.1$ & $500.1-1,000$ & $300.1-500$ & $100.1-300$ & $\leq 100$ \\
\hline
\end{tabular}


The method of designation of the vulnerability index values for land cover was based on the evaluation of the NPS importance of a habitat to support plants and wildlife of the Northwestern Great Plains ecological region (National Park Service, 2014, 2020) and abundance of that habitat in the study area. The soil saturated hydraulic conductivity designation method was based on the Natural Resources Conservation Service (2020) saturated hydraulic conductivity 2003 classes. The accompanying tables for the gSSURGO survey (Natural Resources Conservation Service, 2019) provided saturated hydraulic conductivity for multiple soil layers for any single location so a depth weighted saturated hydraulic conductivity was calculated and relinked to the geographic dataset. Slope was designated based on the definition of a steep slope, which can vary by source (Nashua Regional Planning Commission, 2007; Schoeneberger and others, 2017; Pennsylvania Land Trust Association, 2020). The starting range for steep slopes varied from 15 to 25 percent. To be conservative, a slope greater than 15 percent was selected as a steep slope and used as the upper limit for this assessment. The selected lower slope limit (less than or equal to 3 percent) was defined by Schoeneberger and others (2017) as being nearly level. The low, moderate, and high values were divided between 3- and 15-percent slope limits. Distance to bighorn sheep critical range, springs, rivers and streams, and surficial aquifers was based on estimates of accuracy of the boundaries and the possibility of large spills that may spread farther than a flow path would indicate because the volume of a spill is not considered. ArcGIS Pro (Esri, 2020a) was used for all spatial analysis and generation of critical component vulnerability index values and vulnerability maps.

Stressors within the study area were assessed by generating flow paths, which would be a simulation of a spill. The spill simulation was completed using the flow path tracing tool from the Arc Hydro (Esri, 2020b) toolset, which maps a flow path until it encounters a flat or low point area where the flow direction can no longer be determined. The lidar altitude dataset also was used to generate a flow direction raster to create the flow paths from the stressor data points. If the stressor dataset was a line type feature, such as railroads, highways, and pipelines, then points were generated every 100 meters along the line feature, and flow paths were generated from those points.

\section{Vulnerability Assessment Results}

A vulnerability map for each of the Theodore Roosevelt National Park units (North, Elkhorn Ranch, and South) was generated from the seven vulnerability index values listed in table 2 and is shown in figure $3 A-C$ on sheet 1 (available for download at https://doi.org/10.3133/sim3479). The vulnerability score, computed by summing vulnerability index values, ranged from 0 to 24 in the North Unit and from 0 to 20 in the Elkhorn Ranch and South Units. To better visualize the vulnerability of the study area, the vulnerability score was divided equally into five categories of vulnerability: very low, low, moderate, high, and very high. The highest vulnerability score range was the very high (20-24) category. The areas with this rating were all near surface water, where land cover type, distance to surficial aquifer, and distance to rivers and streams had high vulnerability index values. High (15-19) vulnerability scores also were exclusively near surface water. Moderate (10-14) vulnerability scores were mostly in areas that had deciduous forest, wetland, and woody wetland land cover or bighorn sheep critical range. Low (5-9) and very low $(0-4)$ vulnerability scores were the most common and were in a variety of land cover types that did not have nearby surface water resources.

The stressor flow paths generated from OG development and transportation infrastructure for each of the Theodore Roosevelt National Park units (North, Elkhorn Ranch, and South) are shown in figure $4 A-C$ on sheet 1 . The flow paths generated for all units indicated the highest likelihood of contamination occurring in rivers and streams, particularly in the South Unit (fig. 4C).

The vulnerability maps used in conjunction with the stressor flow path allow for a refined identification of which vulnerable areas are most likely to be contaminated from the surrounding stressors. The vulnerability maps for each Theodore Roosevelt National Park unit identified areas of moderate, high, and very high vulnerability that would be beneficial to examine more closely.

The North Unit had the most areas with moderate, high, and very high vulnerability (fig. $3 A$ ). These areas occurred all across the southern and eastern parts of the unit where the Little Missouri River (fig. 1), surficial aquifers (fig. 1), wetland type land covers, and bighorn sheep critical habitat (fig. 1) are all present. Several stressor flow paths cross these areas from pipelines and highways (fig. $4 A$ ), which represent additional risk factors to the vulnerable areas identified. Only flow paths from along Highway 85 (fig. 2), which crosses the eastern part of the North Unit, flow into the park and present a risk to moderate, high, and very high vulnerability areas nearby. Spills occurring along the pipeline (fig. 2) in the southern part of the North Unit also would be damaging for Theodore Roosevelt National Park because all flow paths in this area flow into the Little Missouri River just upstream from the park.

In the Elkhorn Ranch Unit, areas with moderate, high, and very high vulnerability were in the southeastern part of the unit (fig. $3 B$ ) where, again, the Little Missouri River, surficial aquifer, wetland type land cover, and bighorn sheep critical habitat are present. The stressor flow paths in the Elkhorn Ranch Unit follow the length of the Little Missouri River and all its tributaries in the study area (fig. 4B). The stressor flow paths originated from crude oil wells and pipelines. Only flow paths from crude oil wells (fig. 2) northwest of the Elkhorn Ranch Unit national park boundary cross within the park; the flow paths cross moderate to very low vulnerability areas. Any spills occurring along the pipeline (fig. 2) on the southwestern boundary of the Elkhorn Ranch Unit and at any of the crude 
oil wells within the Elkhorn Ranch Unit have the potential to flow into the Little Missouri River (fig. 1) just upstream from the Elkhorn Ranch Unit and the North Unit or just the North Unit.

In the South Unit, one area had moderate, high, and very high vulnerability scores that were not due entirely to proximity of the river or streams (fig. 3C). This area is in the southcentral part of the South Unit and is where the Little Missouri River and bighorn sheep critical range (fig. 1) are present. The stressor flow paths in the South Unit follow the length of the Little Missouri River and nearly all its tributaries in the study area. Several stressor flow paths that originated from crude oil (fig. 2) wells cross the one identified vulnerable area (fig. 4C). Only flow paths from along Interstate 94 on the south border of the South Unit national park boundary and crude oil wells (fig. 2) north of the park flow into the park directly (they do not enter the park by flowing into the Little Missouri River or tributaries upstream from the park); the flow paths cross moderate to very low vulnerability areas. Spills occurring along Interstate 94 and oil wells in the western and southern part of the South Unit would be damaging for Theodore Roosevelt National Park because all flow paths in this area flow into the Little Missouri River or its tributaries upstream from all the park units.

\section{References Cited}

Amberg, S., Kilkus, K., Komp, M., Nadeau, A., Stark, K., Danielson, L., Gardner, S., Iverson, E., Norton, E., and Drazkowski, B., 2014, Theodore Roosevelt National ParkNatural resource condition assessment: Fort Collins, Colo., National Park Service, Natural Resource Report NPS/ THRO/NRR—2014/776, 258 p.

Eldridge, W.G., and Medler, C.J., 2020, Inventory and analysis of groundwater resources-Theodore Roosevelt National Park, North Dakota: Fort Collins, Colo., National Park Service, Natural Resource Report, NPS/THRO/ NRR_-2020/2124, 125 p., accessed September 2020 at https://irma.nps.gov/DataStore/DownloadFile/639871.

Esri, 2019, USA detailed streams: Redlands, Calif., Esri, digital data, accessed December 2019 at https://www.arcgis. com/home/item.html?id=1e29e33360c8441bbb0186 $63273 \mathrm{a} 046 \mathrm{e}$.

Esri, 2020a, ArcGIS Pro: Redlands, Calif., Esri, software, accessed December 2019 at https://www.esri.com/en-us/ arcgis/products/arcgis-pro/overview.

Esri, 2020b, Arc Hydro-ArcGIS Pro: Redlands, Calif., Esri, software, accessed December 2019 at https://community. esri.com/community/gis/solutions/arc-hydro.
McKenzie County, North Dakota, 2014, McKenzie County LiDAR 2014: North Dakota State Water Commission digital data, accessed August 24, 2018, at https://lidar.swc.nd.gov/.

Nashua Regional Planning Commission, 2007, Steep slopes: Nashua, N.H., Nashua Regional Planning Commission Fact Sheet 12, 2 p., accessed January 6, 2020, at https:// www.nashuarpc.org/files/9413/9042/4971/FS12 Slopes.pdf\#: :text=Steep $\% 20$ slopes $\% 20$ are $\% 20$ legally $\%$ 20defined,of $\% 20$ building $\% 20$ on $\% 20$ steep $\% 20$ grades.

National Park Service, 2014, Foundation documentTheodore Roosevelt National Park. National Park Service, $64 \mathrm{p}$.

National Park Service, 2020, Theodore Roosevelt National Park: National Park Service web page, accessed January 8, 2020, at https://www.nps.gov/thro/index.htm.

Natural Resources Conservation Service, 2017, ND LiDAR Dissemination Map Service: North Dakota State Water Commission digital data, accessed August 24, 2018, at https://lidar.swc.nd.gov/.

Natural Resources Conservation Service, 2019, Geospatial data gateway: U.S. Department of Agriculture, Natural Resources Conservation Service digital data, accessed October 15, 2019, at https://datagateway.nrcs.usda.gov/ GDGOrder.aspx?order=QuickState.

Natural Resources Conservation Service, 2020, Saturated hydraulic conductivity-Water movement concepts and class history: U.S. Department of Agriculture, Natural Resources Conservation Service Soil Survey Technical Note 6, accessed January 8, 2019, at https:/www.nrcs.usda.gov/ wps/portal/nres/detail/soils/ref/?cid=nrcs142p2_053573.

North Dakota Department of Environmental Quality, 2019, Environmental incident reports: North Dakota Department of Environmental Quality, Spill Investigation Program web page, accessed March 16, 2019, at https://deq.nd.gov/WQ/ 4_Spill_Investigations/Reports.aspx.

North Dakota Department of Mineral Resources, 2019a, Wells_-Oil and gas: North Dakota Department of Mineral Resources, ArcIMS Viewer digital data, accessed November 21, 2019, at https://www.dmr.nd.gov/OaGIMS/ viewer.htm.

North Dakota Department of Mineral Resources, 2019b, Gas plants - Oil and gas: North Dakota Department of Mineral Resources, ArcIMS Viewer digital data, accessed November 21, 2019, at https://www.dmr.nd.gov/OaGIMS/ viewer.htm.

North Dakota Department of Transportation, 2019a, Railroads: North Dakota Department of Transportation, North Dakota GIS Hub Data Portal digital data, accessed October 15, 2019, at https://gishubdata.nd.gov/dataset/railroads. 
North Dakota Department of Transportation, 2019b, State and Federal roads: North Dakota Department of Transportation, North Dakota GIS Hub Data Portal digital data, accessed October 15, 2019, at https://gishubdata.nd.gov/dataset/stateand-federal-roads.

North Dakota Game and Fish Department, 2019, Bighorn sheep critical range: North Dakota Game and Fish Department, North Dakota GIS Hub Data Portal digital data, accessed October 15, 2019, at https://gishubdata.nd. gov/dataset/bighorn-sheep-critical-range.

North Dakota State Water Commission, 2019, Surficial aquifers: North Dakota State Water Commission, North Dakota GIS Hub Data Portal digital data, accessed October 15, 2019, at https://gishubdata.nd.gov/dataset/surficial-aquifers.

Pennsylvania Land Trust Association, 2020, Steep slope ordinance: Pennsylvania Land Trust Association web page, accessed January 6, 2020, at https://conservationtools.org/ guides/59-steep-slope-ordinance.

Schoeneberger, P., Wysocki, D., Busskohl, C., and Libohova, Z., 2017, Landscapes, geomorphology, and site description, chap. 2 of Ditzler, C., Scheffe, K., and Monger, H.C., eds., Soil survey manual: U.S. Department of Agriculture, Natural Resources Conservation Service, p. 21-82, accessed January 8, 2020, at https://www.nrcs.usda.gov/wps/portal/ nrcs/detail/soils/ref/?cid=nrcs142p2_054252.
U.S. Energy Information Administration, 2020, Crude oil pipelines - Layer information for interactive State maps: U.S. Energy Information Administration digital data, accessed February 3, 2020, at https://www.eia.gov/maps/ layer_info-m.php.

U.S. Environmental Protection Agency, 2010, Level III Ecoregions of North America Shapefile: U.S. Environmental Protection Agency Office of Research \& DevelopmentNational Health and Environmental Effects Research Laboratory, accessed July 25, 2020, at https://www.epa.gov/ eco-research/ecoregions-north-america.

U.S. Geological Survey, 2011, National Land Cover Dataset (2011): U.S. Department of Agriculture, Natural Resources Conservation Service, GeoSpatial Data Gateway digital data, accessed December 17, 2019, at https://datagateway. nrcs.usda.gov/GDGOrder.aspx?order=QuickState.

U.S. Geological Survey, 2019, USGS water data for the Nation: U.S. Geological Survey National Water Information System database, accessed December 13, 2019, at https://doi.org/10.5066/F7P55KJN. 

For more information about this publication, contact: Director, USGS Dakota Water Science Center

821 East Interstate Avenue, Bismarck, ND 58503

1608 Mountain View Road, Rapid City, SD 57702

605-394-3200

For additional information, visit: https://www.usgs.gov/centers/ dakota-water

Publishing support provided by the

Lafayette and Rolla Publishing Service Centers 


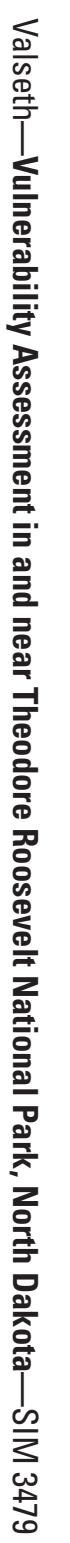

